\title{
Associations of IGF2 and DRD2 polymorphisms with laying traits in Muscovy duck
}

\author{
Qiao Ye ${ }^{1,2}$, Jiguo Xu ${ }^{1,2}$, Xinfeng Gao ${ }^{1,2}$, Hongjia Ouyang ${ }^{1,2}$, Wei Luo ${ }^{1,2}$, Qinghua Nie ${ }^{\text {Corresp. }{ }^{1,2}}$ \\ 1 National-Local Joint Engineering Research Center for Livestock Breeding, Collegeof Animal Science, South China Agricultural University, Guangzhou, \\ Guangdong, China \\ ${ }^{2}$ Key Lab of Chicken Genetics, Breeding and Reproduction, Ministry of Agriculture and Guangdong Provincial Key Lab of Agro-animal Genomics and \\ Molecular Breeding, South China Agricultural University, Guangzhou, Guangdong, China \\ Corresponding Author: Qinghua Nie \\ Email address: nqinghua@scau.edu.cn
}

Insulin-like growth factor 2 (IGF2) and dopamine receptor 2 (DRD2) play important roles in ovarian follicular development. In this study, we analyzed tissue-specific expression of the Muscovy duck IGF2 and DRD2 genes and cloned those genes transcripts. Polymorphisms in these genes were tightly linked with egg production traits and both genes were highly expressed in the ovary. Moreover, we identified 5 single nucleotide polymorphisms (SNPs) for IGF1 and 28 for DRD2. Mutations A-1864G and C-1704G of IGF2 were positively correlated with increased egg laying at 59 weeks (E59W) $(P<0.05)$. The $\mathrm{C}+7 \mathrm{~T}$ and $C+364 G$ mutations of DRD2 were highly and significantly associated with first-egg age (FEA) and egg numbers at 300 days (E300D) $(P<0.01)$. Moreover, $C+3301 \mathrm{G}$ and $C+3545 \mathrm{G}$ of DRD2 were highly significantly associated with FEA, E59W and E300D $(P<$ $0.01)$. Other mutations were positively associated with FEA or E300D or E59W $(P<0.05)$. These data suggest specific roles for IGF1 and DRD2 polymorphisms in egg production in Muscovy ducks. 
1 Associations of $I G F 2$ and $D R D 2$ polymorphisms with laying traits in Muscovy duck

2 Qiao $\mathrm{Ye}^{1,2}$, Jiguo $\mathrm{Xu}^{1,2}$, Xinfeng $\mathrm{Gao}^{1,2}$, Hongjia Ouyang ${ }^{1,2}$, Wei Luo ${ }^{1,2}$, and Qinghua $\mathrm{Nie}^{1,2}$

$4 \quad{ }^{1}$ National-Local Joint Engineering Research Center for Livestock Breeding, Collegeof Animal

5 Science, South China Agricultural University, Guangzhou 510642, Guangdong, China

$6 \quad{ }^{2}$ Key Lab of Chicken Genetics, Breeding and Reproduction, Ministry of Agriculture and

7 Guangdong Provincial Key Lab of Agro-animal Genomics and Molecular Breeding, Guangzhou

8 510642, Guangdong, China

9

10 Corresponding author: Q. H. Nie. E-mail: nqinghua@scau.edu.cn. 


\section{ABSTRACT}

13 Insulin-like growth factor 2 (IGF2) and dopamine receptor 2 (DRD2) play important roles in 14 ovarian follicular development. In this study, we analyzed tissue-specific expression of the

15 Muscovy duck IGF2 and DRD2 genes and cloned those genes transcripts. Polymorphisms in

16 these genes were tightly linked with egg production traits and both genes were highly expressed

17 in the ovary. Moreover, we identified 5 single nucleotide polymorphisms (SNPs) for IGF1 and

1828 for DRD2. Mutations A-1864G and C-1704G of IGF2 were positively correlated with

19 increased egg laying at 59 weeks (E59W) $(P<0.05)$. The $\mathrm{C}+7 \mathrm{~T}$ and $\mathrm{C}+364 \mathrm{G}$ mutations of

20 DRD2 were highly and significantly associated with first egg age (FEA) and egg numbers at 300

21 days (E300D) $(P<0.01)$. Moreover, $\mathrm{C}+3301 \mathrm{G}$ and $\mathrm{C}+3545 \mathrm{G}$ of $D R D 2$ were highly significantly

22 associated with FEA, E59W and E300D $(P<0.01)$. Other mutations were positively associated

23 with FEA or E300D or E59W $(P<0.05)$. These data suggest specific roles for IGF1 and DRD2

24 polymorphisms in egg production in Muscovy ducks.

\section{INTRODUCTION}

Muscovy ducks are an excellent breed species because of their rapid growth, crude feed tolerance and high quality meat. Although these ducks are raised on a large scale in China, low production performance affects the economic interests of farmers. Breeders have been looking for ways to improve Muscovy ducks egg production. In recent years, with the rapid development 
31 of genome sequencing technologies, molecular marker breeding and transgenic breeding

32 technology have gradually become the mainstream of breeding. Traditional breeding mainly

33 depends on breeding experience, which has a lot of unpredictability. Furthermore, molecular

34 breeding can significantly improve breeding efficiency and shorten the breeding period, so using

35 molecular marker breeding has a huge advantage in breeding. Nowadays, molecular markers are

36 widely used in poultry breeding, such as green shell egg related molecular markers (Wang et al.,

37 2013) and egg production related molecular markers (Han et al., 2014). Due to the great

38 prospects of molecular markers in breeding, using molecular markers to selecting high laying

39 performance Muscovy ducks is a good decision.

40 Our research focuses on egg production related molecular markers that can be used to

41 improve egg production for the Muscovy duck. Few researchers have paid attention to egg

42 production traits in Muscovy ducks, which makes our research more meaningful. The first egg

43 age (FEA), egg numbers at 300 days (E300D), and egg numbers at 59 weeks (E59W) are

44 important traits in Muscovy ducks breeding. Muscovy ducks egg peak time is from 35 weeks to

4553 weeks, and 59 weeks is the last stage of laying. 300 days is the peak time of laying, and 59

46 weeks is the end time of laying in Muscovy ducks, which covers most of the egg laying period.

47 Therefore, we focus on FEA, E300D and E59W instead of egg production at other time points as

48 important traits.

Insulin-like growth factor 2 (IGF2) plays a key roles in animal growth differentiation and 
51 development. In mammals, IGF2 is highly expressed in the dominant follicle supporting key

52 functions for follicular development (Mao et al., 2004). IGF2 may affect prolificacy in sows and

53 cattle (Stinckens et al., 2010; Aad et al., 2013), and IGF2 may regulate ovarian development

54 through follicle-stimulating hormone (FSH) (Baumgarten et al., 2015). But little research on the

55 regulation of ovarian development by $I G F 2$ has been conducted in birds. The present study is the

56 first to reportthat IGF2 may be associated with ovarian development. Dopamine (DA) is an

57 essential neurotransmitter and exists in the nerve center and its peripheral tissue. Dopamine receptor 2 (DRD2) may assist with the secretion of reproductive hormones through folliclestimulating hormone (FSH) and luteinizing hormone (LH) in chicken (Youngren et al., 1996; Youngren et al., 1998). Association studies between single nucleotide polymorphisms (SNPs) of $I G F 2$ and DRD2 and reproduction traits have been carried out in poultry (Xu et al., 2011; Wang et al., 2014; Zhang et al., 2015; Zhu et al., 2015). However, until now very few studies have focused on the relevance of these genes to egg production in Muscovy ducks. Therefore, we aim to identify SNPs in these genes, and to reveal their associations with reproduction traits in performance of Muscovy ducks in breeding.

MATERIALS AND METHODS

\section{Ethics Statement}

Ethical approval for all animal experiments was granted by the Animal Care Committee of South 
71 China Agricultural University (Guangzhou, People's Republic of China) with approval number

7220131019002.

\section{Sample Collection}

75 Eight hundred white Muscovy ducks were offered by Wens Nanfang Poultry Breeding company

76 (Yunfu, Guangdong, China) which were in the same run. All Muscovy ducks were reared under

77 identical conditions of management and feeding. Ducks were maintained outside on the ground

78 from 4 to 12 weeks of age, after which they were transferred to individual cages in a

79 semiconfined house. Feed was provided by Wens company. The first egg age (FEA), egg

80 numbers at 300 days (E300D), and egg numbers at 59 weeks (E59W) were recorded for each

81 female duck. Genomic DNA from each individual at 59 weeks was isolated from $0.5 \mathrm{ml}$ blood

82 stored with EDTA as an anticoagulant, using E.Z.N.A NRBC Blood DNA Kit (Omega, Norcross,

83 GA, USA) according to the manufacturer's instructions.

\section{RNA Isolation and cDNA Synthesis}

86 Muscovy duck tissues including pituitary, brain, lung, abdominal fat, liver, ovary, subcutaneous

87 fat, spleen, kidney, leg muscle, hypothalamus, cerebellum, heart and breast muscle used for expression pattern analysis of the IGF2 and DRD2 genes, were sampled at first egg age. These

89 ducks were raised under the same conditions, but in different batches from the eight hundred 
90

91

92

93

94

95

96

97

98

99

100

101

102

103

104

105

106

107

108

109

110

Muscovy ducks mentioned above. Total RNA was isolated from tissues using a TRIZOL

Reagent kit (TaKaRa, Dalian, China) according to the manufacturer's protocol. RNA quality was

evaluated by $2 \%$ agarose gel electrophoresis and then was reverse transcribed using Takara

reverse transcription Kit (TaKaRa, Dalian, China) according to the manufacturer's instructions.

The cDNA was used as template to amplify the coding region of the $I G F 2$ and $D R D 2$ genes from

Muscovy duck.

\section{Cloning of Muscovy duck IGF2 and $D R D 2$ genes}

The Muscovy duck IGF2 and DRD2 genes were identified using Mallard duck gene sequences as a reference (Gene Bank accession No. XM_005019778 and XM_013109685). Primers were designed to amplify the coding regions of Muscovy duck IGF2 and DRD2 using Primer 5.0 (Primer IGF2-CDS and Primer DRD2-CDS; Table S1). PCR amplifications were conducted in a final volume of $50 \mu 1$ with $2 \mu 1$ cDNA, $25 \mu 12 \times$ Easy Taq SuperMix (TransGen, Beijing, China), and $0.5 \mu \mathrm{l}$ each pair of primers, and $22 \mu \mathrm{l}$ double distilled $\mathrm{H}_{2} \mathrm{O}$. Optimum PCR amplification conditions were programmed as pre-denaturation at $94^{\circ} \mathrm{C}$ for $3 \mathrm{~min}$, followed by 35 cycles of denaturation at $94^{\circ} \mathrm{C}$ for $30 \mathrm{~s}$, annealing at $58^{\circ} \mathrm{C}$ for $30 \mathrm{~s}$, and extension at $72^{\circ} \mathrm{C}$ for $30 \mathrm{~s}$, and a final extension at $72^{\circ} \mathrm{C}$ for $10 \mathrm{~min}$. The PCR products were evaluated by electrophoresis using a 2\% agarose gel and then gel purified using a HiPure Gel Pure DNA kit (TransGen, Beijing, China). The amplified fragments were cloned into pMD-18T vector (TaKaRa, Dalian, China), and sequenced by Majorbio, Shanghai, China. Sequence alignment and phylogenetic trees are constructed using MEGA5. 


\section{Expression Pattern Analysis of IGF2 and DRD2 mRNA}

113

114

115

116

117

118

119

120

121

122

123

124

125

126

127

128

129

130

131

132

Total mRNA from 14 different tissues was extracted to investigate the mRNA expression profiles of Muscovy duck IGF2 and DRD2 genes using real-time qPCR. Muscovy duck $\beta$-actin gene was used as the internal reference gene. Primers for the IGF2, DRD2 and $\beta$-actin genes were designed using Primer 5.0 (Primer $\beta$-actin-duck, IGF2-Q and DRD2-Q; Table S1). The qPCR was performed using a standard SYBR Premix Ex Taq II (TaKaRa, Dalian, China) on a BioRad CFX96 Real-Time PCR Detection System (Bio-Rad, Hercules, USA) according to the manufacturer's protocol. The thermal cycling was $95^{\circ} \mathrm{C}$ for $2 \mathrm{~min}$, followed by 39 cycles of $95^{\circ} \mathrm{C}$ for $15 \mathrm{~s}, 60^{\circ} \mathrm{C}$ for $30 \mathrm{~s}, 72^{\circ} \mathrm{C}$ for $30 \mathrm{~s}$, and final cycle of $72^{\circ} \mathrm{C}$ for $7 \mathrm{~min}$. Relative expression of $I G F 2$ and DRD2 genes was calculated relative to the expression of $\beta$-actin. Real-time PCR data were analyzed using the $2^{-\Delta \Delta \mathrm{Ct}}$ method.

\section{SNPs Detection by Sequencing}

We designed 7 primers to identify potential SNPs of IGF2 and DRD2 (Primer IGF2-P1, IGF2-P2, DRD2-P1, DRD2-P2, DRD2-P3, DRD2-P4 and DRD2-P5; Table S1). Twenty white Muscovy ducks were sampled and five individuals were selected as a mixed pool. PCR reactions were performed in a $50 \mu \mathrm{l}$ final volume, containing $2 \mu \mathrm{l}$ DNA, $25 \mu 12 \times$ Easy Taq SuperMix (TransGen Biotech, Beijing, China), $0.5 \mu$ l each pair of primers, and $22 \mu$ d double distilled $\mathrm{H}_{2} \mathrm{O}$. PCR parameters were $3 \mathrm{~min}$ at $94^{\circ} \mathrm{C}$ followed by 37 cycles of $94^{\circ} \mathrm{C}$ for $30 \mathrm{~s}$, annealing temperature for $60 \mathrm{~s}, 72^{\circ} \mathrm{C}$ for $30 \mathrm{~s}$ and a final extension at $72^{\circ} \mathrm{C}$ for $10 \mathrm{~min}$. PCR products were evaluated by electrophoresis using $2 \%$ agarose gel and sequenced as described above. SNPs were 
133 identified by the Seqman program of DNAStar 7.1.0 software.

\section{Genotyping and Association Analysis}

136

137

The SNPs were genotyped in 800 female ducks with egg production records via sequencing. We designed 3 primers to genotyping SNPs of IGF2 and DRD2 (Primer IGF2-SNP, DRD2-SNP1 and DRD2-SNP2; Table S1). PCR reactions were identical to those used in SNP detection as described above. Genotypes were tested for Hardy-Weinberg equilibrium with the chi-square test. Linkage analysis was performed using Haploview software (Barrett et al., 2005). The associations between SNPs and egg production traits were calculated using the general linear model procedure of SAS v. 9.2 with the following model:

$$
Y_{i j}=\mu+G_{i}+\mathrm{e}_{\mathrm{ij}}
$$

where $Y_{i j}$ is the observed value of different egg production traits, $\mu$ is the overall population mean, $G_{i}$ is the effect of each genotype, and $\mathrm{e}_{\mathrm{ij}}$ is the random error. For each egg production trait, the least-squares mean was estimated and differences between the genotypes were analyzed usinga Bonferroni adjustment for multiple comparisons. Difference with $P$ value $\leq 0.05$ was considered to be significant in analyses.

\section{RESULTS}

\section{Characterization of Muscovy duck IGF2 and DRD2 Coding Region}


153 platyrhynchos (XM_013191560.1) and Anser cygnoides domesticus (XM_005019778.2), 154 respectively. We obtained the full-length cDNA of DRD2 including a 52-bp 5'-untranslated 155 region (UTR), an 1104-bp open reading frame (ORF) containing 368 codons and a 294-bp 3'156 UTR. The Muscovy duck DRD2 cDNA sequence was 98\% and 96\% to Anas platyrhynchos 157 (XM_013109686.1) and Anser cygnoides domesticus (XM_013187289.1), respectively. A 158 phylogenetic tree constructed based on the DRD2 gene also revealed that the Muscovy duck was 159 closely related with both animals above (Figure 1).

\section{Tissue Expression of IGF2 and DRD2 Genes}

162

163

164

165

166

167

168

169

170

171

172 173

We examined tissue-specific expression of IGF2 and found that it was expressed in most tissues. The highest expression levels were found in the kidney and ovaries (Figure 2). DRD2 expression was the highest in ovary, but it was also expressed in the cerebrum, cerebellum, hypothalamus and pituitary at lower levels. However, other tissues also had expression levels near detection limits including abdominal fat, sebum and breast and leg muscle. Expression in the spleen was negligible (Figure 3).

\section{Polymorphisms of IGF2 and DRD2 Genes}

We identified 5 SNPs in the 5'flanking region of $I G F 2$, a level of one SNP per 449 bp on average. These SNPs were A-1864G, C-1704G, A-584G, A-227G and A-183G (Table 1). We found 28 SNPs in DRD2 giving rise to one SNP per 317 bp on average. Among them, the SNP $\mathrm{C}+7 \mathrm{~T}$ in exon 1 was a missense mutation resulting in a $\mathrm{P}$ to $\mathrm{S}$ amino acid change (Table 1). We 
174 selected 2 SNPs of IGF2 and 11 SNPs of DRD2, based on mixed pool sequencing results which

175 indicated that these were more likely to be associated with egg laying traits, for further

176 association analysis.

\section{Association of $I G F 2$ and $D R D 2$ with egg production traits}

179

180

181

182

183

184

Association analysis indicated thatthe A-1864G and C-1704G SNPs of IGF2 gene were both significantly associated with E59W $(P<0.05)$ (Table 2$)$, and linkage disequilibrium analysis indicated a high linkage block between A-1864G and C-1704G for IGF2 (Figure 4). Multiple comparisons of different genotypes showed that the AG genotype individuals of A-1864G had 67 eggs more than GG genotype individuals for E59W $\quad(P<0.01)$. The GG genotype individuals of C-1704G had 7-8 eggs more than individuals with the CC genotype for E59W $(P<0.05)$.

Association analysis for $\mathrm{DRD} 2$ gene further showed that $\mathrm{C}+7 \mathrm{~T}$ and $\mathrm{C}+364 \mathrm{G}$ had highly significant associations with FEA and E300D $(P<0.01)$ and were significantly associated with E59W $(P<0.05)$ (Table 3). A+3489G, A+3484T and T+3428C were significantly associated with FEA and E300D $(P<0.05)$, and highly associated with E59W $(P<0.01)$ T $+3423 \mathrm{C}$ and A $+3262 \mathrm{G}$ were significantly associated with FEA $(P<0.05)$ and highly significantly associatedwith E59W $(P<0.01)$ A $+3183 \mathrm{C}$ was significantly associated with E59W $(P<0.05)$, and $\mathrm{T}+3024 \mathrm{C}$ has no significant association with any of thethree egg production traits. Moreover, it was notable that $\mathrm{C}+3301 \mathrm{G}$ and $\mathrm{C}+3545 \mathrm{G}$ were highly significantly associated with FEA, E59W and E300D $(P<0.01)$. Multiple comparisons among different genotypes showed that the GG genotypes of $\mathrm{C}+3301 \mathrm{G}$ and $\mathrm{C}+3545 \mathrm{G}$ were advantageous for earlier egg laying and egg production. There were two high linkage blocks $(\mathrm{C}+7 \mathrm{~T}$ and $\mathrm{C}+364 \mathrm{G}, \mathrm{A}+3183 \mathrm{C}$ and $\mathrm{A}+3262 \mathrm{G})$ 
196

197

198

199

200

201

202

203

204

205

206

207

208

209

210

211

212

213

214

for DRD2 (Figure 5).

\section{DISCUSSION}

Muscovy duck is an excellent poultry, but its egg production is low, which has been plaguing farmers and breeders. In recent years, molecular marker breeding has gradually become the mainstream of breeding, and many breeders try to improve egg laying performances through breeding methods of molecular markers in poultry (Wang et al., 2014; Fulton et al., 2012; Uemoto et al., 2009). Using molecular marker to improve Muscovy ducks egg production is an effective method which will greatly improve the economic value of Muscovy ducks. Our study focused on egg production traits and related molecular markers, and we tried to find some molecular markers highly related to egg production in Muscovy ducks, with the hope thatthey can be used in Muscovy duck breeding. We believe that the relevant personnel of Muscovy ducks industry will havea strong interest in this study.

for the first time, which will be a great help in future research. IGF2 and DRD2 genes in humans, mice and chickens all have transcript variants (Kaalund et al., 2014; Wernersson et al., 2015; Johannessen et al., 2016). However, we only found one transcripts in Muscovy duck. This may be caused by differences between different species. 
215 (Irwin et al., 2012). In our study, we found IGF2 is widely expressed in different tissues with the

216 highest expression in ovary. This suggests that IGF2 may be associated with ovarian

217 development. The ovarian functions of birds are regulated by luteinizing hormone (LH) and

218 follicle stimulating hormone (FSH). IGF2 can stimulate granule cell proliferation and related

219 hormones synthesis and regulate follicle development with FSH in mammals (Lucy, 2011).

220 Previous studies have found that $I G F 2$ expression in the ovary directly affects the development

221 of dominant follicles in rats (Wang et al., 2002). IGF1 can inhibit the apoptosis of granulosa

222 cells, while IGF2 might regulate cell proliferation during follicular development in chicken

223 (Johnson et al., 2009). In addition, IGF2 expression in the follicles of highly productive chickens

224 are significantly higher than that in lowly productive chickens. Therefore, a relationship exists

225 between the expression of IGF2 in the ovary and egg production in chickens (Kim et al., 2004).

226 It is also becoming clear from in vivo and in vitro studies carried out in birds that IGF2 plays an

227 important role in ovarian follicular development (Wood et al., 2005). All these studies indicate

228 that $I G F 2$ is related to the development of ovary. Thus, we deduced that $I G F 2$ might play a key

229 role in ovarian follicular development of Muscovy ducks and regulate egg production.

230 In this study, we found that Muscovy DRD2 also had its highest expression in the ovary.

231 The $D R D 2$ gene belongs to the catecholamine neurotransmitter receptors that exist widely in

232 central and peripheral nervous tissues. $D R D 2$ is highly expressed in the ovary and this may be

233 related to follicular and ovarian development in human (Morton et al., 2006). Other studies

234 identified high $D R D 2$ expression in the regulation of reproductive functions in grey mullet

235 (Nocillado et al., 2007). DRD2 agonist can inhibit the production and secretion of vascular 
236 endothelial growth factor protein in human granulosa cells (Ferrero et al., 2014). Together these

237 findings indicate that DRD2 may have a function in follicular and ovarian development.

238 Therefore, we selected $I G F 2$ and $D R D 2$ as a candidate gene related to egg laying traits for 239 further study.

$240 \quad I G F 2$ is important in body growth and development. Most research on IGF2 has 241 concentrated on growth studies and the association of $I G F 2$ polymorphisms with growth related 242 traits. Few studies have investigated the association between IGF2 and egg laying traits. But in 243 the current study, we found the high linkage sites A-1864G and C-1704G of IGF2 were 244 significantly associated with E59W. This indicated that $I G F 2$ was positively related to egg laying 245 traits. However, we have not studied how those two loci of IGF2 regulate egg laying 246 performance. A futurestudy should focus on the function of the two loci for egg laying 247 performance. Recently, DRD2 polymorphisms have been related to poultry egg production. Our 248 previous studies found the chicken $D R D 2$ gene polymorphisms were correlated with the first egg 249 age and the egg numbers at 300 days in chicken (Xu et al., 2011). SNPs of DRD2 were 250 significantly associated with egg production at 38 weeks and egg weight at 300 days in chicken 251 (Zhu et al., 2015). These studies suggest that the DRD2 is indeed associated with the laying 252 performance of birds. In our study, we also found a link between DRD2 and the laying 253 performance of birds. We found 10 SNPs of $D R D 2$ gene $(C+7 T, C+364 G, A+3183 C, A+3262 G$, $\mathrm{C}+3301 \mathrm{G}, \mathrm{T}+3423 \mathrm{C}, \mathrm{T}+3428 \mathrm{C}, \mathrm{A}+3484 \mathrm{~T}, \mathrm{~A}+3489 \mathrm{G}$ and $\mathrm{C}+3545 \mathrm{G})$ were significantly associated with egg production traits, and two high linkage blocks were found in haplotype analysis. According to our studies, IGF2 and DRD2 are indeed related to the laying performance 257 of birds, but the specific functions of these SNPs remain to be studied. 
259 correlated with egg laying performance in Muscovy ducks. These molecular markers highly 260 associated with egg production traits can be used in Muscovy duck breeding. It is conducive to

261 the development of the whole industry of Muscovy ducks. However, the functional mechanisms 262 of these SNPs affecting egg production await further investigation.

\section{REFERENCES}

Aad P Y, Echternkamp S E, Spicer L J. 2013. Possible role of IGF2 receptors in regulating selection of 2 dominant follicles in cattle selected for twin ovulations and births. Domestic Animal Endocrinology. 45:187-195.

Barrett J C, Fry B, Maller J, Daly M J. 2005. Haploview: Analysis and visualization of LD and haplotype maps. Bioinformatics. 21:263-265.

Baumgarten S C, Convissar S M, Zamah A M, Fierro M A, Winston N J, Scoccia B, Stocco C. 2015. FSH regulates IGF-2 expression in human granulosa cells in an AKT-Dependent manner. Journal of Clinical Endocrinology and Metabolism. 100:E1046-E1055.

Ferrero H, Garcíapascual C M, Pellicer N, Simón C, Pellicer A, Gómez R. 2014. Dopamine agonist inhibits vascular endothelial growth factor protein production and secretion in granulosa cells. Reproductive Biology \& Endocrinology. 13:1247-1256.

Fulton J E, Soller M, Lund A R, Arango J, Lipkin E. 2012. Variation in the ovocalyxin-32 gene in commercial egg-laying chickens and its relationship with egg production and egg quality traits. 
Animal Genetics. 43 Suppl 1:102-113.

Han C, An G, Du X. 2014. Three novel single nucleotide polymorphisms of the 3-hydroxy-3methylglutaryl coenzyme a reductase gene associated with egg-production in chicken. Folia Biologica. 62:203-209.

Irwin D A, Van Der Kraak G. 2012. Regulation and actions of insulin-like growth factors in the ovary of zebrafish (Danio rerio). General and Comparative Endocrinology. 177:187-194.

Johannessen L E, Panagopoulos I, Haugvik S P, Gladhaug I P, Heim S, Micci F. 2016. Upregulation of INS-IGF2 read-through expression and identification of a novel INS-IGF2 splice variant in insulinomas. Oncology Reports.

Johnson A L, Bridgham J T, Swenson J A. 2009. Activation of the Akt/protein kinase B signaling pathway is associated with granulosa cell survival. Biology of Reproduction. 64:1566-1574.

Kaalund S S, Newburn E N, Ye T, Tao R, Li C, Deep-Soboslay A, Herman M M, Hyde T M, Weinberger D R, Lipska B K, Kleinman J E. 2014. Contrasting changes in DRD1 and DRD2 splice variant expression in schizophrenia and affective disorders, and associations with SNPs in postmortem brain. Molecular Psychiatry. 19:1258-1266.

Kaneda A, Wang C J, Cheong R, Timp W, Onyango P, Wen B, Iacobuzio-Donahue C A, Ohlsson R, Andraos R, Pearson M A, Sharov A A, Longo D L, Ko M S, Levchenko A, Feinberg A P. 2007. Enhanced sensitivity to IGF-II signaling links loss of imprinting of IGF2 to increased cell proliferation and tumor risk. Proceedings of the National Academy of Sciences. 104:20926-20931. 
297 Kim M H, Seo D S, Ko Y. 2004. Relationship between egg productivity and insulin-like growth factor-I

298

299

300

301

302

303

304

305

306

307

308

309

310

311

312

313

314

genotypes in Korean native Ogol chickens. Poultry Science. 83:1203-1208.

Lucy M C. 2011. Growth hormone regulation of follicular growth. Reproduction, fertility, and development. 24:19-28.

Mao J, Smith M F, Rucker E B, Wu G M, Mccauley T C, Cantley T C, Prather R S, Didion B A, Day B N. 2004. Effect of epidermal growth factor and insulin-like growth factor I on porcine preantral follicular growth, antrum formation, and stimulation of granulosal cell proliferation and suppression of apoptosis in vitro. Journal of Animal Science. 82:1967-1975.

Morton L M, Wang S S, Bergen A W, Chatterjee N, Kvale P, Welch R, Yeager M, Hayes R B, Chanock S J, Caporaso N E. 2006. DRD2 genetic variation in relation to smoking and obesity in the Prostate, Lung, Colorectal, and Ovarian Cancer Screening Trial. Pharmacogenet Genomics. 16:901-910.

Nocillado J N, Levavi-Sivan B, Carrick F, Elizur A. 2007. Temporal expression of G-protein-coupled receptor 54 (GPR54) gonadotropin-releasing hormones $(\mathrm{GnRH})$, and dopamine receptor D2 (drd2) in pubertal female grey mullet, Mugil cephalus. General \& Comparative Endocrinology. 150:278-287.

Stinckens A, Mathur P, Janssens S, Bruggeman V, Onagbesan O M, Schroyen M, Spincemaille G, Decuypere E, Georges M, Buys N. 2010. Indirect effect of IGF2 intron3 g.3072G\&gt;a mutation on prolificacy in sows. Animal Genetics. 41:493-498.

Uemoto Y, Suzuki C, Sato S, Sato S, Ohtake T, Sasaki O, Takahashi H, Kobayashi E. 2009. Polymorphism of the ovocalyxin-32 gene and its association with egg production traits in the chicken. 
Wang C, Liu Y, Wang H, Wu H, Gong S, Chen W, He D. 2014. Molecular characterization and differential expression of multiple goose dopamine D2 receptors. Gene. 535:177-183.

319

320

321

322

Wang Y, Asselin E, Tsang B K. 2002. Involvement of transforming growth factor alpha in the regulation of rat ovarian X-linked inhibitor of apoptosis protein expression and follicular growth by folliclestimulating hormone. Biology of Reproduction. 66:1672-1680.

Wang Y, Xiao L H, Zhao X L, Liu Y P, Zhu Q. 2014. Identification of SNPs in cellular retinol binding protein 1 and cellular retinol binding protein 3 genes and their associations with laying performance traits in erlang mountainous chicken. Asian-Australasian Journal of Animal Sciences. 27:1075-1081.

Wang Z, Qu L, Yao J, Yang X, Li G, Zhang Y, Li J, Wang X, Bai J, Xu G, Deng X, Yang N, Wu C. 2013. An EAV-HP insertion in 5' Flanking region of SLCO1B3 causes blue eggshell in the chicken. PLoS Genetics. 9:e1003183.

Wernersson R, Frogne T, Rescan C, Hansson L, Bruun C, Gronborg M, Jensen J N, Madsen O D. 2015. Analysis artefacts of the INS-IGF2 fusion transcript. BMC Molecular Biology. 16:13.

Wood A W, Schlueter P J, Duan C. 2005. Targeted knockdown of insulin-like growth factor binding protein-2 disrupts cardiovascular development in zebrafish embryos. Molecular Endocrinology. 19:1024-1034.

Xu H P, Zeng H, Zhang D X, Jia X L, Luo C L, Fang M X, Nie Q H, Zhang X Q. 2011. Polymorphisms 
334

335

associated with egg number at 300 days of age in chickens. Genetics \& Molecular Research. 10:2279-2289.

Xu H, Hua Z, Luo C, Zhang D, Qian W, Liang S, Yang L, Min Z, Nie Q, Zhang X. 2011. Genetic effects of polymorphisms in candidate genes and the QTL region on chicken age at first egg. BMC Genetics. $12: 33$

Youngren O M, Chaiseha Y, El H M. 1998. Serotonergic stimulation of avian prolactin secretion requires an intact dopaminergic system. General and Comparative Endocrinology. 112:63-68.

Youngren O M, Pitts G R, Phillips R E, El H M E. 1996. Dopaminergic control of prolactin secretion in the turkey. General \& Comparative Endocrinology. 104:225-230.

Zhang D X, Xu Z Q, He J, Ji C L, Zhang Y, Zhang X Q. 2015. Polymorphisms in the 5'-flanking regions of the GH, PRL, and Pit-1 genes with Muscovy duck egg production. Journal of Animal Science. 93:28-34.

Zhu L, Li D, Xu L, Han X, Wu G. 2015. Correlation between DRD2 gene polymorphism and early egg production performance of libo yaoshan chicken. Animal Husbandry \& Feed Science.:208-211. 
349 Table 1 SNPs identified in the IGF2 and $D R D 2$ genes

\begin{tabular}{|c|c|c|c|c|}
\hline No. & Gene & SNPs ${ }^{1}$ & Location $^{2}$ & Amino acid change \\
\hline 1 & $I G F 2$ & A-1864G & $5^{\prime}$ regulatory region & No \\
\hline 2 & $I G F 2$ & C-1704G & 5 ' regulatory region & No \\
\hline 3 & $I G F 2$ & A-584G & 5 ' regulatory region & No \\
\hline 4 & $I G F 2$ & A-227G & $5^{\prime}$ regulatory region & No \\
\hline 5 & $I G F 2$ & A-183G & 5 ' regulatory region & No \\
\hline 6 & $D R D 2$ & C-300G & $5 '$ regulatory region & No \\
\hline 7 & DRD2 & A-251T & 5 ' regulatory region & No \\
\hline 8 & DRD2 & $\mathrm{T}-237 \mathrm{G}$ & $5 '$ regulatory region & No \\
\hline 9 & $D R D 2$ & A-194G & 5 ' regulatory region & No \\
\hline 10 & DRD2 & A-84G & 5 ' regulatory region & No \\
\hline 11 & DRD2 & $\mathrm{C}+7 \mathrm{~T}$ & Exon 1 & Yes (P-S) (ccc-tcc) \\
\hline 12 & $D R D 2$ & $\mathrm{C}+364 \mathrm{G}$ & Intron 1 & No \\
\hline 13 & DRD2 & $\mathrm{A}+476 \mathrm{~T}$ & Intron 1 & No \\
\hline
\end{tabular}




\begin{tabular}{|c|c|c|c|c|}
\hline 14 & DRD2 & $\mathrm{T}+830 \mathrm{G}$ & Intron 1 & No \\
\hline 15 & $D R D 2$ & $\mathrm{~T}+3024 \mathrm{C}$ & Intron 1 & No \\
\hline 16 & DRD2 & $A+3183 C$ & Intron 2 & No \\
\hline 17 & DRD2 & $A+3262 G$ & Intron 2 & No \\
\hline 18 & $D R D 2$ & $\mathrm{C}+3301 \mathrm{G}$ & Intron 2 & No \\
\hline 19 & DRD2 & $\mathrm{T}+3423 \mathrm{C}$ & Intron 2 & No \\
\hline 20 & $D R D 2$ & $\mathrm{~T}+3428 \mathrm{C}$ & Intron 2 & No \\
\hline 21 & DRD2 & $\mathrm{A}+3484 \mathrm{~T}$ & Intron 2 & No \\
\hline 22 & $D R D 2$ & $A+3489 G$ & Intron 2 & No \\
\hline 23 & $D R D 2$ & $C+3545 G$ & Intron 2 & No \\
\hline 24 & $D R D 2$ & $\mathrm{~T}+6859 \mathrm{G}$ & Intron 5 & No \\
\hline 25 & DRD2 & $\mathrm{T}+6986 \mathrm{C}$ & Intron 5 & No \\
\hline 26 & $D R D 2$ & $\mathrm{~T}+7099 \mathrm{C}$ & Intron 5 & No \\
\hline 27 & DRD2 & $\mathrm{T}+7295 \mathrm{C}$ & Intron 5 & No \\
\hline 28 & DRD2 & $\mathrm{T}+7537 \mathrm{C}$ & Exon 6 & No \\
\hline
\end{tabular}




$\begin{array}{lllll}29 & \text { DRD2 } & \mathrm{C}+7654 \mathrm{G} & \text { 3' regulatory region } & \text { No } \\ 30 & \text { DRD2 } & \mathrm{T}+8309 \mathrm{G} & \text { 3' regulatory region } & \text { No } \\ 31 & \text { DRD2 } & \mathrm{A}+8442 \mathrm{G} & \text { 3' regulatory region } & \text { No } \\ 32 & \text { DRD2 } & \mathrm{T}+8585 \mathrm{C} & \text { 3' regulatory region } & \text { No } \\ 33 & \text { DRD2 } & \mathrm{A}+8770 \mathrm{G} & \text { 3' regulatory region } & \text { No }\end{array}$

Notes.

351

${ }^{1}$ SNPs means single nucleotide polymorphisms, referred to covered regions, the first nucleotide of the translation

352 start codon was designated +1 , with the next upstream nucleotide being -1 .

$353{ }^{2} 5^{\prime}$ regulatory region $=5$ ' flanking and untranslated region; 3' regulatory region $=3$ ' flanking and untranslated 354 region. 


\begin{tabular}{|c|c|c|c|c|c|}
\hline $\mathrm{SNPs}^{1}$ & Traits $^{2}$ & \multicolumn{3}{|c|}{ Least-squares mean $\pm \mathrm{SEM}^{3}$} & $P$-value \\
\hline & & $\mathrm{AA}(\mathrm{n}=204)$ & $\mathrm{AG}(\mathrm{n}=308)$ & $\mathrm{GG}(\mathrm{n}=172)$ & \\
\hline \multirow[t]{4}{*}{ A-1864G } & FEA & $276.60 \pm 1.41^{\mathrm{a}}$ & $275.67 \pm 1.15^{\mathrm{a}}$ & $276.77 \pm 1.54^{\mathrm{a}}$ & 0.8087 \\
\hline & E59W & $75.35 \pm 1.92^{\mathrm{a}}$ & $76.01 \pm 1.57^{\mathrm{a}}$ & $69.18 \pm 2.10^{\mathrm{b}}$ & 0.0251 \\
\hline & E300D & $21.43 \pm 1.04^{\mathrm{a}}$ & $21.91 \pm 0.85^{\mathrm{a}}$ & $20.84 \pm 1.14^{\mathrm{a}}$ & 0.7533 \\
\hline & & $\mathrm{CC}(\mathrm{n}=158)$ & $\mathrm{CG}(\mathrm{n}=310)$ & $\mathrm{GG}(\mathrm{n}=216)$ & \\
\hline \multirow[t]{3}{*}{ C-1704G } & FEA & $276.50 \pm 1.61^{\mathrm{a}}$ & $276.43 \pm 1.15^{\mathrm{a}}$ & $275.72 \pm 1.37^{\mathrm{a}}$ & 0.9067 \\
\hline & E59W & $68.92 \pm 2.19^{\mathrm{b}}$ & $75.33 \pm 1.56^{\mathrm{a}}$ & $76.11 \pm 1.87^{\mathrm{a}}$ & 0.0254 \\
\hline & E300D & $20.97 \pm 1.19^{\mathrm{a}}$ & $21.18 \pm 0.85^{\mathrm{a}}$ & $22.33 \pm 1.01^{\mathrm{a}}$ & 0.6050 \\
\hline
\end{tabular}

Notes.

translation start codon was designated +1 , with the next upstream nucleotide being -1 .

\footnotetext{
${ }^{3}$ Values within a row with no common superscript differ significantly $(P<0.05)$ or are highly significant
} 
$(P<0.01)$. 
365 Table 3 Association of 11 SNPs at DRD2 gene with egg production traits in Muscovy duck

\begin{tabular}{|c|c|c|c|c|c|}
\hline $\mathrm{SNPs}^{1}$ & Traits ${ }^{2}$ & \multicolumn{3}{|c|}{ Least-squares mean \pm SEM $^{3}$} & $P$-value \\
\hline & & $\mathrm{CC}(\mathrm{n}=387)$ & $\mathrm{CT}(\mathrm{n}=237)$ & $\mathrm{TT}(\mathrm{n}=31)$ & \\
\hline \multirow[t]{4}{*}{$\mathrm{C}+7 \mathrm{~T}$} & FEA & $272.95 \pm 0.90^{c}$ & $276.30 \pm 1.15^{\mathrm{b}}$ & $295.94 \pm 3.17^{\mathrm{a}}$ & $<0.0001$ \\
\hline & E59W & $74.62 \pm 1.35^{\mathrm{a}}$ & $75.34 \pm 1.73^{\mathrm{a}}$ & $61.13 \pm 4.78^{\mathrm{b}}$ & 0.0187 \\
\hline & E300D & $22.90 \pm 0.71^{\mathrm{a}}$ & $21.81 \pm 0.91^{\mathrm{a}}$ & $8.42 \pm 2.51^{\mathrm{b}}$ & $<0.0001$ \\
\hline & & $\mathrm{CC}(\mathrm{n}=22)$ & $\mathrm{CG}(\mathrm{n}=239)$ & $\mathrm{GG}(\mathrm{n}=394)$ & \\
\hline \multirow[t]{4}{*}{$\mathrm{C}+364 \mathrm{G}$} & FEA & $297.00 \pm 3.80^{\mathrm{a}}$ & $275.64 \pm 1.15^{\mathrm{b}}$ & $273.79 \pm 0.90^{\mathrm{b}}$ & $<0.0001$ \\
\hline & E59W & $62.32 \pm 5.67^{\mathrm{b}}$ & $77.15 \pm 1.72^{\mathrm{a}}$ & $73.14 \pm 1.34^{\mathrm{ab}}$ & 0.0193 \\
\hline & E300D & $9.86 \pm 3.01^{\mathrm{b}}$ & $22.37 \pm 0.91^{\mathrm{a}}$ & $22.16 \pm 0.71^{\mathrm{a}}$ & 0.0003 \\
\hline & & $\mathrm{TT}(\mathrm{n}=130)$ & $\mathrm{TC}(\mathrm{n}=160)$ & $\mathrm{CC}(\mathrm{n}=410)$ & \\
\hline \multirow[t]{4}{*}{$\mathrm{T}+3024 \mathrm{C}$} & FEA & $276.27 \pm 1.75^{\mathrm{a}}$ & $275.21 \pm 1.58^{\mathrm{a}}$ & $277.19 \pm 0.98^{\mathrm{a}}$ & 0.5547 \\
\hline & E59W & $79.02 \pm 2.37^{\mathrm{a}}$ & $72.81 \pm 2.13^{\mathrm{ab}}$ & $72.77 \pm 1.33^{b}$ & 0.0594 \\
\hline & E300D & $21.94 \pm 1.30^{\mathrm{a}}$ & $21.37 \pm 1.17^{\mathrm{a}}$ & $20.80 \pm 0.73^{a}$ & 0.7271 \\
\hline & & $\mathrm{CC}(\mathrm{n}=143)$ & $\mathrm{AC}(\mathrm{n}=182)$ & $\mathrm{AA}(\mathrm{n}=375)$ & \\
\hline
\end{tabular}




\begin{tabular}{|c|c|c|c|c|c|}
\hline \multirow[t]{3}{*}{$A+3183 C$} & FEA & $276.84 \pm 1.67^{\mathrm{a}}$ & $278.16 \pm 1.48^{\mathrm{a}}$ & $275.67 \pm 1.03^{\mathrm{a}}$ & 0.3816 \\
\hline & E59W & $69.38 \pm 2.25^{b}$ & $72.85 \pm 2.00^{\mathrm{ab}}$ & $76.21 \pm 1.39^{\mathrm{a}}$ & 0.0301 \\
\hline & E300D & $21.02 \pm 1.24^{\mathrm{a}}$ & $19.98 \pm 1.09^{\mathrm{a}}$ & $21.75 \pm 0.76^{a}$ & 0.4124 \\
\hline & & $\mathrm{GG}(\mathrm{n}=205)$ & $\mathrm{AG}(\mathrm{n}=269)$ & $\mathrm{AA}(\mathrm{n}=226)$ & \\
\hline \multirow[t]{4}{*}{$A+3262 G$} & FEA & $278.86 \pm 1.39^{\mathrm{a}}$ & $276.85 \pm 1.21^{\mathrm{ab}}$ & $274.15 \pm 1.32^{\mathrm{b}}$ & 0.0466 \\
\hline & E59W & $69.75 \pm 1.88^{b}$ & $73.88 \pm 1.64^{\mathrm{ab}}$ & $77.80 \pm 1.79^{\mathrm{a}}$ & 0.0084 \\
\hline & E300D & $19.50 \pm 1.03^{\mathrm{b}}$ & $21.06 \pm 0.90^{\mathrm{ab}}$ & $22.72 \pm 0.98^{\mathrm{a}}$ & 0.0766 \\
\hline & & $\mathrm{GG}(\mathrm{n}=132)$ & $\mathrm{CG}(\mathrm{n}=231)$ & $\mathrm{CC}(\mathrm{n}=337)$ & \\
\hline \multirow[t]{4}{*}{$\mathrm{C}+3301 \mathrm{G}$} & FEA & $272.05 \pm 1.72^{b}$ & $279.36 \pm 1.30^{\mathrm{a}}$ & $276.42 \pm 1.08^{\mathrm{a}}$ & 0.0033 \\
\hline & E59W & $80.70 \pm 2.34^{\mathrm{b}}$ & $73.11 \pm 1.77^{\mathrm{a}}$ & $71.86 \pm 1.46^{\mathrm{a}}$ & 0.0052 \\
\hline & E300D & $24.77 \pm 1.28^{\mathrm{a}}$ & $19.26 \pm 0.96^{\mathrm{b}}$ & $21.01 \pm 0.80^{\mathrm{b}}$ & 0.0028 \\
\hline & & $\mathrm{TT}(\mathrm{n}=135)$ & $\mathrm{TC}(\mathrm{n}=245)$ & $\mathrm{CC}(\mathrm{n}=320)$ & \\
\hline \multirow[t]{3}{*}{$\mathrm{T}+3423 \mathrm{C}$} & FEA & $277.77 \pm 1.71^{\mathrm{a}}$ & $278.80 \pm 1.27^{\mathrm{a}}$ & $274.35 \pm 1.11^{\mathrm{b}}$ & 0.0226 \\
\hline & E59W & $67.96 \pm 2.31^{\mathrm{b}}$ & $73.13 \pm 1.72^{\mathrm{ab}}$ & $77.08 \pm 1.50^{\mathrm{a}}$ & 0.0038 \\
\hline & E300D & $20.13 \pm 1.27^{\mathrm{ab}}$ & $19.89 \pm 0.94^{\mathrm{b}}$ & $22.53 \pm 0.82^{\mathrm{a}}$ & 0.0730 \\
\hline
\end{tabular}




$$
\mathrm{TT}(\mathrm{n}=47) \quad \mathrm{TC}(\mathrm{n}=154) \quad \mathrm{CC}(\mathrm{n}=499)
$$

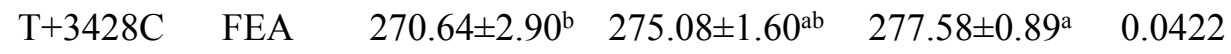

E59W $\quad 85.72 \pm 3.92^{\mathrm{a}} \quad 76.16 \pm 2.16^{\mathrm{b}} \quad 72.14 \pm 1.20^{\mathrm{b}} \quad 0.0022$

E300D $\quad 25.87 \pm 2.15^{\mathrm{a}} \quad 22.16 \pm 1.19^{\mathrm{ab}} \quad 20.38 \pm 0.66^{\mathrm{b}} \quad 0.0317$

$$
\mathrm{TT}(\mathrm{n}=145) \quad \mathrm{AT}(\mathrm{n}=141) \quad \mathrm{AA}(\mathrm{n}=414)
$$

$\mathrm{A}+3484 \mathrm{~T} \quad$ FEA $\quad 272.65 \pm 1.65^{\mathrm{b}} \quad 278.96 \pm 1.67^{\mathrm{a}} \quad 277.13 \pm 0.97^{\mathrm{a}} \quad 0.0183$

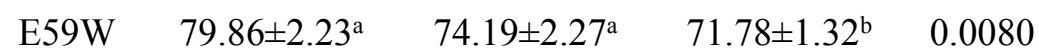

E300D $\quad 24.17 \pm 1.22^{\mathrm{a}} \quad 19.40 \pm 1.24^{\mathrm{b}} \quad 20.67 \pm 0.72^{\mathrm{b}} \quad 0.0141$

$\mathrm{GG}(\mathrm{n}=140) \quad \mathrm{AG}(\mathrm{n}=218) \quad \mathrm{AA}(\mathrm{n}=342)$

$\begin{array}{llllll}A+3489 G & \text { FEA } & 278.66 \pm 1.68^{\mathrm{a}} & 278.69 \pm 1.34^{\mathrm{a}} & 274.35 \pm 1.07^{\mathrm{b}} & 0.0159\end{array}$

$\begin{array}{lllll}\text { E59W } & 67.56 \pm 2.27^{\mathrm{b}} & 72.51 \pm 1.82^{\mathrm{b}} \quad 77.46 \pm 1.45^{\mathrm{a}} & 0.0008\end{array}$

E300D $\quad 19.99 \pm 1.24^{\mathrm{ab}} \quad 19.56 \pm 1.00^{\mathrm{b}} \quad 22.61 \pm 0.80^{\mathrm{a}} \quad 0.0343$

$\mathrm{GG}(\mathrm{n}=198) \quad \mathrm{CG}(\mathrm{n}=180) \quad \mathrm{CC}(\mathrm{n}=322)$

$\begin{array}{llllll}C+3545 G & \text { FEA } & 272.70 \pm 1.41^{\mathrm{b}} & 276.78 \pm 1.47^{\mathrm{a}} & 278.81 \pm 1.10^{\mathrm{a}} & 0.0029\end{array}$

$\begin{array}{lllll}\text { E59W } & 79.74 \pm 1.91^{\mathrm{a}} & 73.11 \pm 2.00^{\mathrm{b}} & 70.84 \pm 1.49^{\mathrm{b}} & 0.0011\end{array}$ 


\section{E300D $\quad 24.26 \pm 1.04^{\mathrm{a}} \quad 21.02 \pm 1.09^{\mathrm{b}} \quad 19.29 \pm 0.82^{\mathrm{b}} \quad 0.0009$}

366 Notes.

367 Data are summarized as means \pm SEM

368 'SNPs means single nucleotide polymorphisms, referred to covered regions, the first nucleotide of the

369 translation start codon was designated +1 , with the next upstream nucleotide being -1 .

$370 \quad{ }^{2} \mathrm{FEA}=$ first egg age; E59W = egg number at age 59 weeks; E300D = egg number at age 300 days.

$371 \quad{ }^{3}$ Values within a row with no common superscript differ significantly $(P<0.05)$ or are highly significant

$372 \quad(P<0.01)$. 


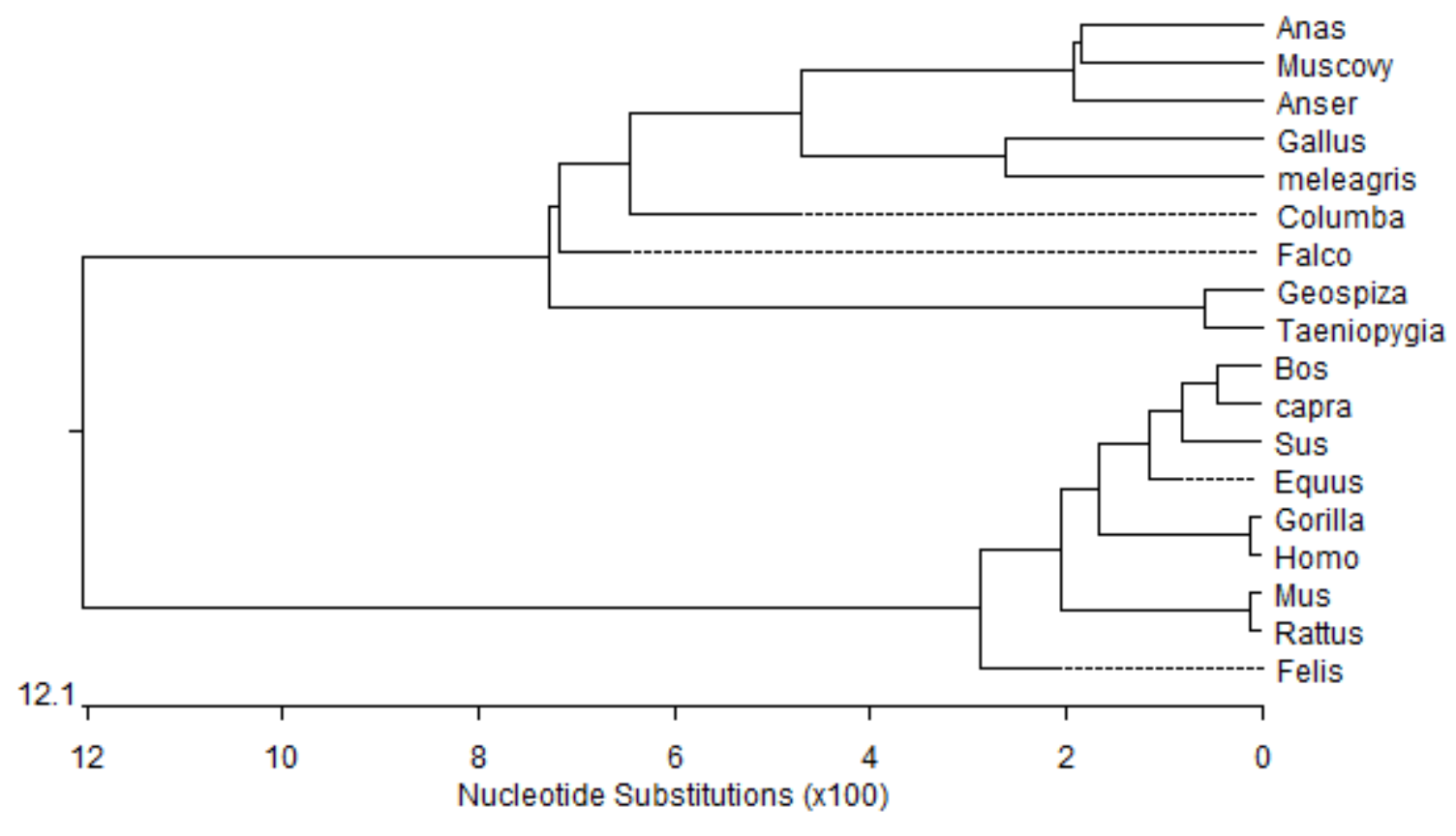

375 Figure 1 Phylogenetic tree of Muscovy duck DRD2 aligned amino acid sequences.

376 Orthologs were analyzed using Clustal W. 


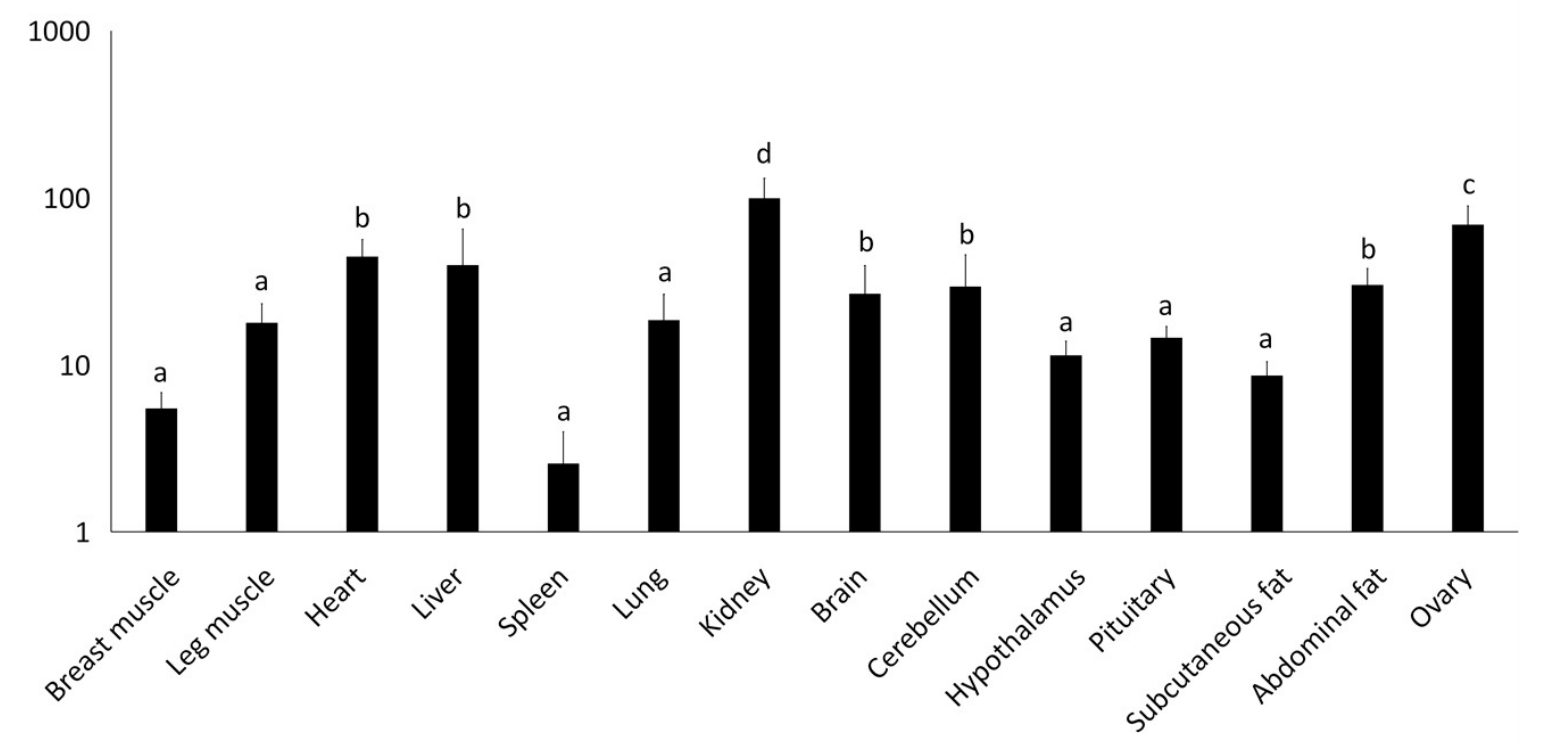

379 Figure 2 Total mRNA expression of the IGF2 gene in different tissues of the Muscovy duck.

The value in the $\mathrm{Y}$ axis indicated $2^{-\Delta \Delta \mathrm{Ct}}$ value. 


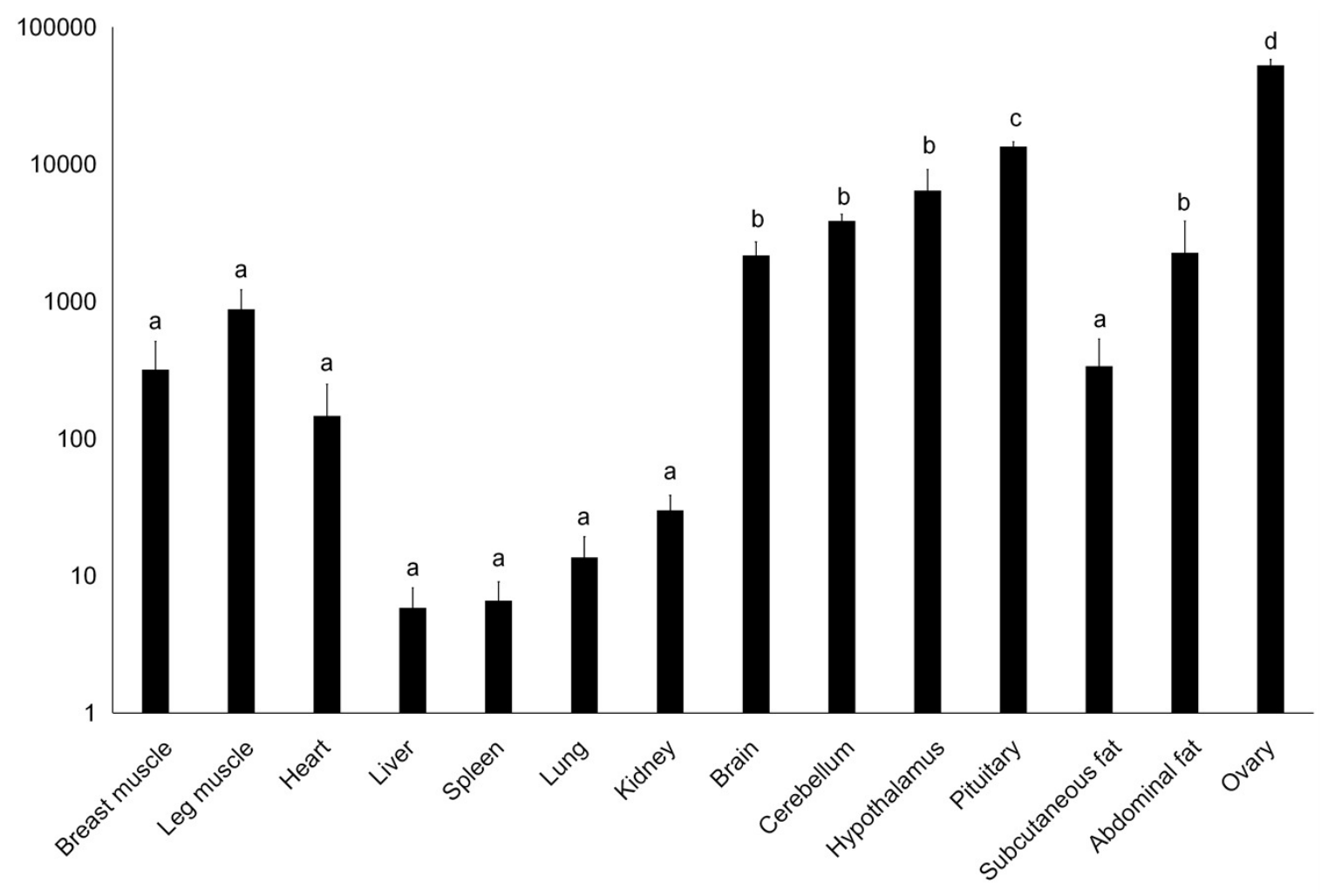

Figure 3 Total mRNA expression of the DRD2 gene in different tissues of the Muscovy

duck. The value in the $\mathrm{Y}$ axis indicated $2^{-\Delta \Delta \mathrm{Ct}}$ value. 


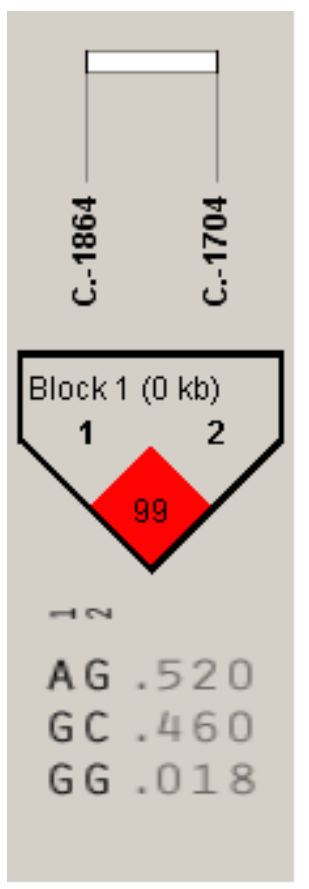

386

387 Figure 4 The linkage status of 2 identified SNPs in IGF2 gene. The color of block indicates

388 the LD status of SNPs; deep red means high linkages between two SNPs. 


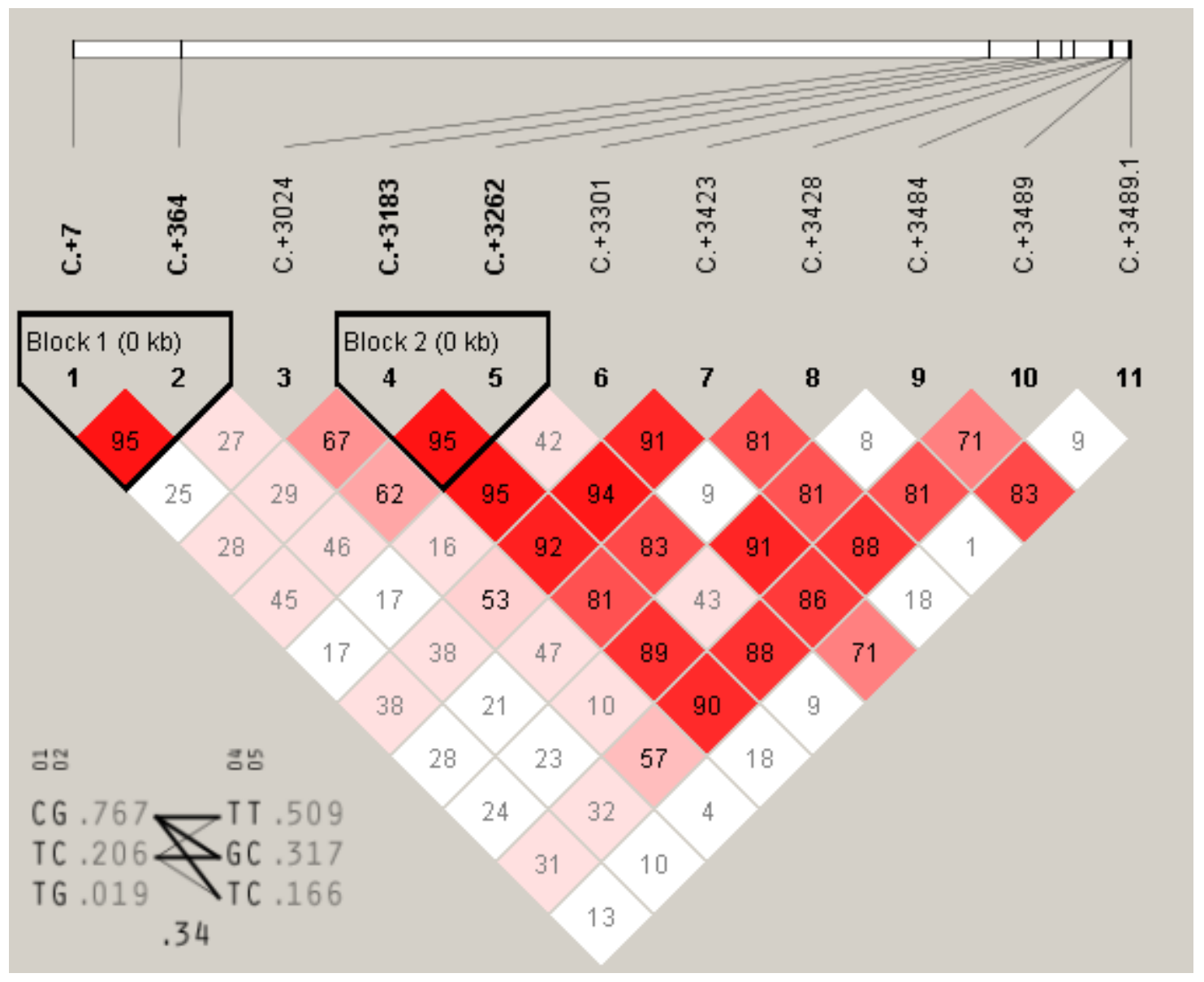

391 Figure 5 The linkage status of 11 identified SNPs in DRD2 gene. The color of block indicates

392 the LD status of SNPs; deep red means high linkages between two SNPs. 